\title{
The Indian Claims Commission Act
}

\author{
By Nancy Oestreich Lurie
}

Abstract: Awareness of the specific need for solving problems of jurisdiction and finance in Indian litigation, a growing feeling that Indian claims should receive more speedy and just attention, and administrative expedience combined to cause Congress to adopt the Indian Claims Commission Act in 1942 and to extend it ten years later to 1962. The author describes the types of claims that arise and discusses some of the issues involved with special reference to the role of expert testimony by anthropologists, whose views have been sought in order to clarify such matters as the identification of tribes and the original boundaries of their lands.-Ed.

$\mathrm{T}$ HE Indian Claims Commission Act embodies a number of remarkable legal features as a reflection of problems that have arisen in dealings between the United States and the various Indian tribes. The actual prosecution of suits in accordance with the terms of the Act has led in turn to certain interpretations and procedural aspects of special interest to social scientists. The following discussion will consider these historical and recent phases in the development and application of the Indian Claims Commission Act. ${ }^{2}$

The Act, approved August 13, 1946, was to remain in effect for ten years;

\footnotetext{
1 It must be noted that many of the claims discussed are still pending. Thus, my analyses, apart from specific points duly cited, are my own view's based on personal observation, experience, and research as an expert witness and are not to be construed as the views of the Indian tribes or attorneys by whom I have been employed. While maintaining my personal responsibility for this article, I would like to thank the many colleagues whose stimulating discussions of a variety of Indian claims have suggested factual and theoretical insights. I would particularly like to thank Dr. Angie Debo who had begun research for this study and graciously forwarded her notes for my use.
}

all claims had to be filed within five years from the date of approval. Due to the large number of cases that had not yet been heard or adjudicated by 1956 , the Act was extended in all its details until April 10,1962.2 The Commission is presided over by a chief commissioner and two associate commissioners; Indian petitioners are represented by private attorneys; and the United States is defended against Indian claims by attorneys of the Department of Justice. The Commission has promulgated rules of procedure, but the rules of evidence applicable are comparable to any federal court.

The Act creating the Indian Claims Commission is of relatively recent date, but the need for such legislation had long been recognized for a variety of reasons. Primary among these was the problem of defining jurisdiction in Indian litigation. Although the United States Court of Claims was established in 1855 to permit suit to be brought against the government, by 1863 tribal claims based on treaties were excluded from the general jurisdiction of the 2 C. 949,60 Stat. 1049 ; 25 U.S.C. 70; P.L. 767, Eighty-fourth Congress, Second Session.

Nancy O. Lurie, Ph.D., Ann Arbor, Michigan, is lecturer in Anthropology, University of Michigan, and i'as Research Associate in North American Ethnology, Peabody Museum, Harvard University. She has written numerous articles on the American Indian for professional journals. 
court. $^{3}$ Like foreign nations, it was necessary for each tribe to obtain a special jurisdictional act from Congress in order to present its case in the United States Court of Claims. This arrangement was discriminatory in that tribes differed in the amount of political influence they could command and in having effective legislative spokesmen for their cases. It was also an expensive and time-consuming procedure, since each claim required a virtual trial in Congress whereby cause for granting a special act might be demonstrated. If such an act were granted, the provisions allowed the tribe as a basis of suit were frequently construed in such a narrow way that it was difficult to obtain a full consideration of tribal grievances in the Court of Claims. The result was that a majority of petitions was dismissed by the court.

\section{Problems of Jurisdiction and Finance in Litigations}

A tabulation covering the years 1881 1950 revealed that of 118 claims presented by Indian tribes before the Court of Claims, only thirty-four were allowed recovery. Lawyers were understandably reluctant to represent Indian clients in light of the highly spcialized na-

3 Act of March 3, 1863, 12 Stat. 765.

4 "Tabulation Showing Highly Speculative Nature of Indian Tribal Suits," Court of Claims Nos. 45585, 46640, 47564, 47566; affidavit of Ernest L. Wilkinson Respecting in The Above Captioned Cases, pp. ii, appendix 2,3 . This information was compiled in connection with the celebrated claim of the Ute Indians of Colorado which resulted in a compromise judgment of just over $\$ 31,000,000$. It was the largest award ever made in an Indian claim and larger than the total of all other awards made in Indian claims in the Court of Claims. Despite these spectacular aspects, it was typical of Indian litigation in other respects. The attorneys' fees were set at less than 9 per cent of the final judgment, and the case covered eighteen years from the time contracts were signed until the final amount was settled (1932-1950). ture of the litigation and the small likelihood of recovery. Furthermore, many attorneys recognized that Indian grievances often arose out of concepts of a cultural and social nature not covered by customary interpretations of American law, but that these grievances deserved special recognition. For example, the Winnebago case, Docket No. M-421 in the Court of Claims, was begun in 1928 and finally dismissed in 1942. This time lag as well as the negative outcome was typical of a category of cases connected with the removal of tribes from one place to another.

The tribe claimed restitution on the basis that they had been removed from a reservation in Minnesota to one in South Dakota without their consent. The consequent hardships involving the death of many Winnebago by starvation and exposure forced the rest to flee from South Dakota if they hoped to survive. Ultimately, a majority of these Indians settled among the Omaha where their present reservation was granted to them. Their efforts to become acculturated in Minnesota had been interrupted, many of their older leaders had died in the removal, and their social and cultural life was disrupted and disorganized by the shift in reservations. Although the characterization of the government as "generous" in the final dismissal of the case may sound ironic, it was proper in legal terms. The Court of Claims measured cause for recovery in regard to comparable land values, and the last reservation in question was equal to the first reservation, if not exceeding it in value. The fact that the Winnebago for many years actually resided in the small timbered area of the reservation, being unable to utilize the agricultural lands placed at their disposal in Nebraska, was beyond the jurisdiction of the court. Likewise, the loss of the agricultural land through the machinations of vari- 
ous white people could not be considered in the case. Situations of this nature illustrated that the real causes of Indian complaints were not being met in the Court of Claims.

Apart from the problem of jurisdiction was the matter of claims which were never pressed although they might have stood a good chance of recovery in the Court of Claims. These were the cases of tribes which had inadequate funds or no funds at all with which to prepare and prosecute their cases.

Along with the awareness of the specific need to solve the questions of jurisdiction and finance in Indian litigation, there gradually developed a public sentiment that justice was due the Indians which required attention. However, this component of conscience which led to the eventual passage of the Indian Claims Commission Act was underscored by two matters of administrative expediency. First, notwithstanding the discouraging statistics in regard to recovery in Indian claims, as Indians became increasingly cognizant of their rights before the law, Congress was petitioned with ever greater frequency for special jurisdictional acts. These cases exhibited certain common features that suggested the possibility of creating some general jurisdictional legislation, thereby saving time and money for both the government and the Indians.

Second, the unsettled claims were recognized as contributing to the difficulties attendant on the over-all administration of Indian affairs. As early as 1928 the situation was summarized succinctly in a special report dealing with Indian problems:

The benevolent desire of the United States government to educate and civilize the Indians cannot be realized with a tribe which has any considerable unsatisfied bona fide claim against the government. The expectation of large awards making all members of the tribe wealthy, the disturbing influ- ence of outside agitators seeking personal emoluments, and the conviction in the Indian mind that justice is being denied, renders extremely difficult any cooperation between the government and its Indian wards. Besides these practical considerations, the simple canons of justice and morality demand that no Indian tribe should be denied the opportunity to present for adjustment before an appropriate tribunal the rights which the tribe claims under recognized principles of law and government. 5

The insistence in the above report that legal steps of a judicial nature be taken points up another category of Indian claims besides those which could be dealt with in the Court of Claims if jurisdiction were granted by Congress. Cases in which Congress might grant direct relief will be given special consideration in the discussion of jurisdictional provisions in the Indian Claims Commission Act. It may be noted here, however, that such claims relied even more heavily on the caprice of Congress than did claims arising out of treaties.

\section{Features of Indian Clatms Commission ACT}

As a result of the attempt to deal with the sundry issues raised in Indian litigation, the Indian Claims Commission Act contains several features unique in the history of American jurisprudence. It is important to study the Act in detail at this point since the interpretations and regularizations of procedure, which have grown out of the application of the law, are often mistaken for the law itself. Curiously, the general results of cases to date have tended toward a conservative interpretation of the substantive aspects. The procedure in the presentation of evidence and the evidence itself have taken a course that

${ }^{5}$ Lewis Meriam and Associates, The Problem of Indian Administration (Baltimore: Institute for Government Research, 1928), p. 805. 
was not within the scope of prediction or expectation of those responsible for the Act.

Apparently, the feature dealt with most easily was the financing of Indian cases. Section 15 of the Act sets forth in detail the arrangements regarding legal representation. Special reference to fees for Indians' attorneys points up two unusual matters. Where tribes are unable to invest in any expenses of litigation, and this is the usual situation, cases may be conducted on an entirely contingent basis. This provision is at sharp variance with ordinary regulations of legal practice. An attorney taking a case of this type risks losing his entire investment. Furthermore, any attorney winning a judgment in favor of his clients may receive no more than 10 per cent of the net judgment, aside from actual expenses incurred in the prosecution of the case. It should be noted that claims which do not involve Indians may result in attorneys' fees covering as much as 25 to 50 per cent of the final award. Despite these stringent regulations, Indians have apparently experienced little difficulty in finding attorneys to take their cases. This may be attributed in part to the huge land areas involved-conceivably the entire United States and a large portion of Alaska-so that even 10 per cent of a judgment appeared to be a sizable sum worth an attorney's efforts. ${ }^{\circ}$

\footnotetext{
- Mention should also be made of those attorneys who for many years had been concerned about the discriminatory and complicated aspects involved in Indian claims cases. They greeted the Indian Claims Commission Act as a long needed legal measure and were ready to represent Indian clients under its provisions. No history of the Indian Claims Commission Act is complete without reference to the instrumental role of two attorneys. Ernest L. Wilkinson, as noted in note 4 above, was able to supply a full understanding of the difficulties to be overcome in dealing with Indian litigation, while the late Felix Cohen, Assistant Solicitor in the Department of the In-
}

Once cases began to be heard, the wording of the Act required interpretation, and, as a consequence, attention has centered on four primary problems. These are the identity of the petitioners, the grounds for suit, the presentation of specialized evidence, and the assessment of land values. The matter of evidence must be considered at the outset since it relates to the other problems. Section 13 (b) also of the Act states that the Commission shall establish an "Investigation Division" to search for evidence in the documents and records of the Court of Claims and the several government departments. Such information is to be submitted to the Commission and also to be made available to the Indians involved and to any interested federal agency. The division has never been established, presumably because it was not considered necessary, and funds were never allocated for this purpose. Section 13 (b) provides for the taking of depositions from aged Indians and other individuals having direct knowledge of claims to be presented.

However, it soon became obvious that evidence would consist of more than official documents or records and direct testimony of Indians or their neighbors. Such evidence required organization and interpretation by experts skilled in work of this type. Consequently, anthropological and historical analyses began to play an important part in claims litigation. Critical study of literature concerning given tribes was buttressed with ethnographic accounts. These offered more complete information and more accurate descriptions than the direct testimony of Indians taken according to the format of legal depositions. Archeological investigations provided information where documentary and ethnographic information was incomplete. Even the

terior at the time the Act was passed, concerned himself deeply with its provisions as a matter of federal duty. 
assessment of land values required a background of historical understanding. Again, the Act makes no specific mention of anthropological or historical expertise, but the provisions of Section 18 regarding testimony and the Commission's rules of procedure are sufficiently broad to admit such testimony. ${ }^{7}$

\section{Anthropological Testimony}

The Court of Claims had used anthropological testimony on only three occasions and no precedents in testimony had been established in this regard, so that the role of expert witness was a new one for archeologists, ethnologists, and ethnohistorians. When differing theoretical positions, analyses, and terminology began to loom significantly in the final outcome of the cases, anthropologists became upset and took little comfort from attorneys' assurances that even mathematicians and engineers differed in their expert testimony. Many anthropologists have suggested that the investigation division be activated and that it provide for the inclusion of testimony by anthropological consultants to deal with specialized information and interpretations. It has also been suggested that pretrial discussions be permitted between experts who felt that the differences in their testimony were more apparent than real and was due to the nature of questions put to them in a litigious situation. However, to date, standard legal procedure has been followed with both the Department of Justice and the Indians' attorneys examining their own experts and cross-examining their opponents' witnesses. The special problems usually considered by these witnesses then concern matters of

7 Donald C. Gormley, "The Role of the Expert Witness," Enthnohistory, Vol. 2, No. 4 (1955), pp. 326-46, discusses expertise generally and with special reference to anthropological testimony in connection with the Indian Claims Commission Act.
Indian identity and grounds for suit. Land values, which enter later into the proceedings, have been the special province of land assessors and historians and will be discussed in another connection.

Turning to the question of identity, Section 2 of the Act sets forth a description of the petitioners which is intended to include all likely claimants within the jurisdiction of the Commission: "any tribe, band, or other identifiable group of American Indians residing within the territorial limits of the United States or Alaska." Due to the reliance on anthropologists, these terms have given rise to unexpected semantic complications. One scholar's tribe is another scholar's band; some writers have used the terms synonymously; other anthropologists distinguish different types of tribes and bands depending on their historic origins. Thus, in the case of the Lower or Idaho Kootenai, the social identity of this populational entity was an initial point at issue. Docket 154 before the Indian Claims Commission describes the petitioner as the "Kootenai Tribe or Band of Indians of the State of Idaho," which is an admissible dual designation employed by attorneys to deal with the equivocal wording of the Act. Nevertheless, it was argued by the defense that perhaps the Idaho Kootenai had no right to bring a separate suit as a distinct social entity since the Kootenai in Docket 61 were already bringing suit in the claim of the "Confederated Salish and Kootenai Tribes of the Flathead Reservation, Montana." The similarity of names, and the fact that the area claimed was included in the treaty map which was the basis of the Montana tribes' claim, suggested that the Idaho Kootenai were but a geographic subdivision of a single Kootenai tribe. The Montana Kootenai recognized the separate tribal identity of the Idaho Kootenai and stipulated to that effect. 
Documentary evidence along with ethnographic information indicated that only the historic accident of linguistic similarity accounted for the designation of the two tribes as "Upper Kootenai" and "Lower Kootenai" in a largely Salish-speaking area. Earlier literature indicated that completely different names were used for each tribe. The Idaho Kootenai had not only been absent from the treaty negotiations of 1855 , but for many years were unaware that their lands had been included within the cession boundaries. Although specific definitions of groups must thus be adduced in each case on the basis of distinctive customs, genealogies, locations and the like, the question of a general definition is repeated over and over by attorneys for the petitioners and for the defense: "Now, Doctor, how would you define the word tribe? ... In your opinion, do the petitioner Indians conform to this definition?"

\section{Definitions of Indian Social ENTITIES}

The phrase "identifiable group of American Indians" appeals to anthropologists as having general utility in distinguishing a cohesive and recognizable social entity whereby the varied and special connotations of tribe and band might be bypassed. Unfortunately, this term has also been construed in different ways. It may have an ethnological and historical basis like tribes or bands. It may also have a legal basis in terms of groups derived as treaty entities or in terms of "statutory groups" created by Congress for administrative expediency, such as "The Indians of California."

The problem of identity goes deeper than simply defining a society, but implies factors of time and socio-cultural continuity. It is necessary to establish the historic relationship of Indians bringing suit as the rightful heirs to recovery for claims originating one or more generations in the past. In a majority of cases the claims refer to a period from which there are no living survivors. Section 2 provides that all defenses except laches and statutes of limitations may be used by the United States, so that the time covered between the origin of a claim and the hearing regarding it may be a century or longer.

The complications arising in these in stances are many and varied. A frequent historic accident was the geographic separation of what was once a single tribe, holding a common territory, into several smaller groups. Such is the case of the Sac and Fox, Ioway, Potawatomi, Winnebago, and many others. Another common situation is that of several tribes who signed a joint treaty and were located on a single reservation. These tribes now have a general tribal council which does not represent the component tribes. Thus, their separate histories must be disentangled, as in the cases of the Confederated Salish and Kootenai tribes already mentioned, the Confederated tribes of the Colville reservation, the Three Affiliated Tribes of the Fort Berthold reservation, and others. ${ }^{8}$

${ }^{8}$ To the layman, the identity of petitioners' legal representatives becomes almost as complex as the identity of the petitioners themselves. According to section 10 of the Act, tribal organizations authorized by the Secretary of the Interior have the exclusive right to bring claims in behalf of their tribes. Where there is no such council, any member may bring a claim in behalf of his tribe. In some tribes different factions have retained different firms of attorneys who have had to make common cause in the Indians' interests. Sometimes a tribe has been divided into separate geographical enclaves, each having a council and its own attorneys who work together in bringing suit in a claim common to all of the branches of the tribes. Several firms may share the burden of preparing contingent cases with the understanding that all will share to an appropriáte amount in any judgment which may be awarded. 
On the Northwest coast another type of confusion may be seen in the fact that in the 1850's the treaty commissioners were directed to combine little tribes into big tribes and locate as many as possible on single reservations. The Quileute of the Olympic Peninsula offer an example of this situation. These people lived at the mouth of the Quileute River and in a few villages located further upstream. The question arose as to whether the various villages brought together on a single Quileute reservation represented separate little tribes which ought each to bring suit, or whether all formed an original tribe. There seemed to be little question, at least in the minds of the petitioner Indians and their attorneys, that all of the people on the Quileute River belonged to one tribe as indicated by genealogies and other cultural data. However, other villages located on the neighboring $\mathrm{Hoh}$ River also spoke Quileute and seemed to be part of the same tribe on the basis of kinship and common customs. They had been reluctant to move to the Quileute reservation and were eventually given a tiny reservation on the Hoh River. Since the claim embraced the watersheds of the Hoh and Quileute Rivers as one large tract, the identity of the petitioners was assured in Docket 155 with the complicated designation of: "The Quileute Tribe of Indians, on its own behalf, Quileute Tribe of Indians, on its own behalf and on behalf of the Hoh Tribe or Band of Indians; Hoh Tribe or Band of Indians, on the relation of and represented by Scott Fisher, on its own Behalf."

In other cases the attempt at consolidation of claims as a single tribe has been unsuccessful. A number of Chippewa brought a common suit as the Chippewa nation since they had been so designated in various treaties. When the claim, Docket No. 126, was first brought to the Court of Claims, the
Chippewa nation was directed to reduce the matter into the separate claims of the component bands of the Chippewa nation. Chippewa claims later heard by the Commission were likewise set forth on the basis of separate bands. The Commission took a similar view concerning the Ottawa Case, Docket No. 2, where the Ottawa were interpreted as comprising several bands notwithstanding treaty terminology concerning the Ottawa nation.

\section{Claims Categories}

Similar to the difficulties raised in the latitude of jurisdiction in the description of petitioners are those involved in the broad grounds for claims. The five categories of claims as set forth in Section 2 of the Indian Claims Commission Act will be discussed in the order given.

(1) Claims in law or equity arising under the Constitution, laws, treaties of the United States and Executive Orders of the President; (2) all other claims in law or equity, including those sounding in tort with respect to which the claimant would be entitled to sue in a court of the United States if the United States was subject to suit; (3) claims which would result if the treaties, contracts, and agreements between the United States were revised on the ground of fraud, duress, unconscionable consideration, mutual or unilateral mistake, whether of law or fact, or any other ground cognizable by a court of equity; (4) claims arising from the taking by the United States, whether as a result of treaty of cession or otherwise, of lands owned or occupied by claimant without payment for such lands of compensation agreed to by the claimant; and (5) claims based on fair and honorable dealings that are not recognized by any existing rule of law or equity.

The first two clauses admit of easy interpretation according to ordinary legal tenets, but clauses three, four, and five bear special notice as being peculiar to Indian litigation and without precedent in American law. In regard to the third 
clause, the Chief of the Indian Claims Section of the Department of Justice has noted:

Treaties between the United States and foreign nations have been freely construed by our courts, but never before has any court had any jurisdiction to "revise" a treaty. This has always been considered a political matter completely outside the scope of judicial inquiry. And technically this separation of powers has been preserved for you will notice that the Commission and the courts are not given authority to actually revise the treaty but only to grant relief "as if" the treaty were revised."

Clause four was the subject of much legal debate until it was finally settled that the Indian Claims Commission has jurisdiction over claims based on "Indian title," that is, title derived from the simple use and occupancy of a given land. The Department of Justice made strenuous but unsuccessful efforts to eliminate such aboriginal title claims from the Indian Claims Commission Act when the Act was under consideration for amendment to extend its tenure for five years beyond 1957. The question was settled on the outcome of two important cases which will be discussed. However, the historical circumstances underlying the legal reasoning in these cases must be reviewed.

The terms "time immemorial" and "Indian title" figure so prominently in discussions of Indian claims that it is surprising to note that neither phrase occurs anywhere in the Indian Claims Commission Act. Nor do the terms imply, as is often erroneously assumed, that Indian tribes must establish their claims as aboriginal holdings since "time immemorial." However, the theory of

\footnotetext{
9 Ralph Barney, "Legal Problems Peculiar to Indian Claims Litigation," Ethnohistory, Vol. 2, No. 4 (1955), p. 316. The total article, pp. 315-25, notes, among other matters, further instances in the difficulties of designating the petitioner Indians.
}

immemorial possession is fundamental to Indian claims to land in general since the United States' dealings with the Indians rested on precedents established by earlier governments such as those of France and England; and these governments recognized Indians as the original occupants of the American continent. France entered into various agreements with different tribes whereby French sovereignty was extended over Indian country, but it was understood that the Indians would remain in possession of the soil and retain its use as was their customary wont. England, being more interested in actual colonization, declared that land acquired from Indians should be paid for, although English sovereignty was already established in a territory as a replacement of Indian sovereignty or that of another European nation. The crown also reserved the right to enter into such purchases and denied private citizens the authority to buy land directly from the Indians. ${ }^{10}$

\section{United States Treaties with INDIANS}

The United States followed this reasoning in entering into treaties with Indians as if they were foreign nations. The Treaty of Greenville in 1795 is an outstanding early example in this connection, since the Indians had been soundly defeated and United States sovereignty extended over the Ohio Valley on the basis of conquest. Neverthe-

10 "Important Western State Papers," Collections of the State Historical Society of Wisconsin, Vol. 11 (1888), pp. 26-63, reprints an interesting series of rare documents and cites others illustrating this sequence of French, English, and American philosophies of sovereignty in regard to the Old Northwest. In this connection, Section 12 of the Trade and Intercourse Act of 1802 (2 Stat. 139) also enunciates the doctrine that land negotiations with Indians must be made pursuant to the Constitution and are not the province of private citizens. 
less, the tribes concerned were paid for the cession of territory east of the line designated in the treaty to separate white settlement from Indian lands. ${ }^{11}$ However, in some instances land was simply appropriated by white settlers and the Indians dispersed without compensation before treaties could be negotiated. In other cases, Indians remained on certain land which was later secured to them by Acts of Congress or Executive Orders of the President. Finally, some lands were held under Indian title, that is, without special recognition and of ten for long periods of time. Usually this was done with the understanding that some official recognition would eventually be made. In the last category was the case of the Tee-HitTon Indians of Alaska which raised many questions and a good deal of consternation among Indians' lawyers in terms of possible relationships to claims before the Commission. In 1951 these Indians filed a claim before the Court of Claims for compensation for timber taken by the United States. Recovery was not allowed, and the case was brought before the Supreme Court which

11 The Northwest Ordinance of 1787, reenacted and confirmed in 1789 (1 Stat. 50), underlay such provisions as are illustrated in the Treaty of Greenville:

"The utmost good faith shall always be observed towards the Indians; their lands and property shall never be taken from them without their consent; and in their property, rights and liberty they shall never be invaded or disturbed, unless in just and lawful wars authorized by Congress; but laws founded in justice and humanity shall, from time to time, be made, for preventing wrongs being done to them, and for preserving peace and friendship with them."

These features were in effect extended to the Louisiana Territo:y in 1804 by an Act of Congress (2 Stat. 283).

The status of Indian tribes as nations was not only implied in the fact that treaties were negotiated with them but in the opinion of Chief Justice Marshall in 1823 in Johnson v. McIntosh, 8 Wheat, U.S. 543. affirmed the negative decision of the Court of Claims.

The majority opinion, written by $\mathrm{Mr}$. Justice Reed, begins with the observation that:

This is not a case that is connected with any phase of the policy of Congress, continued throughout our history, to extinguish Indian title through negotiation rather than by force, and to grant payments from the public purse to needy descendants of exploited Indians.

Indian title was then discussed in terms of sovereignty held over such land by the United States through conquest. It was decided that Indian title is merely the right of occupancy, not property, and places the government under no obligation to compensate Indians for such lands. This type of title is "unrecognized" in comparison to "recognized title" deriving from treaties or Acts of Congress; only recognized title would be compensable. Since the TeeHit-Ton Indians based their claims on the Fifth Amendment, the opinion concludes that in affirming the decision of the Court of Claims, "it leaves with Congress, where it belongs, the policy of Indian gratuities for the termination of Indian occupancy of Governmentowned land rather than making compensation for its value a rigid constitutional principle." It was also stated in the opinion that Congress has power to take or use Indian title without compensation, but makes provision for tribes to recover for wrongs, "as a matter of grace, not because of legal liability." 12

Taken as whole, the decision might have implied that all cases of Indian title would have to be recognized by Congress before being submitted to judicial processes. Applied to claims pend-

12 Tee-Hit-Ton Indians v. United States, 348 U.S. 272, 273, 282, 291 (1955); the decision of the Court of Claims is reported in 128 Court of Claims 82 (1954). 
ing before the Indian Claims Commission, it was questioned whether or not the decision might lead to exclusion of all cases of Indian title from the general jurisdiction of the Commission. A test was provided in 1953 when the Otoe and Missouria case, in which the Commission recognized the government liable under Indian title, was appealed to the Court of Claims. ${ }^{13}$

The Court of Claims sustained the decision of the Indian Claims Commission, ${ }^{14}$ and the Supreme Court declined to review the case. ${ }^{15}$ The phrase in clause four, "claims . . . as the result of treaty of cession or otherwise . . .," was finally clarified to include Indian title within the jurisdiction of the Commission. Congress, in passing a general jurisdictional act, had fulfilled provisions lacking in the Tee-Hit-Ton case which had reached the Supreme Court directly through the Court of Claims. The sigh of relief of Indian tribes and their attorneys was said to be audible for miles around.

\section{Jurisdictional Provisions of Clause Five}

The final jurisdictional clause concerning "fair and honorable dealings" has been the subject of much debate and has never been settled in the manner of Indian title. The government has argued consistently that it means moral claims and is not intended as an alternative method of securing relief in the event that a case is not proven under technical legal rules. However, in one case at least, the disparity between the price paid a claimant for lands and the then current market value of the lands was so great that the Commissioners entered a judgment for the difference on the basis of clause five. They stated that while there might not have been

132 Indian Claims Commission 335.

14131 Court of Claims 593.

15350 U.S. 848. sufficient basis for a claim on the grounds of unconscionable consideration, yet the evidence did demonstrate a lack of fair and honorable dealings with the Otoe and Missouria Indians on the part of the United States. ${ }^{20}$

Despite the broad jurisdictional provisions, especially in clause five, Indians' attorneys have found it expedient to base claims for restitution on tangible and measurable considerations. As a result, the majority of claims have centered in land to such an extent that the Commission is understandably, albeit erroneously, referred to as the "Indian Land Claims Commission." Although our courts have granted judgments for "mental anguish" and similar grounds, these have been individual claims and have thus apparently influenced the thinking of the Commissioners. One of the first claims decided by the Commission was that of the strvivors of $\mathrm{Ge}$ ronimo's band of Apaches for unfair imprisonment, and it was dismissed as being based on individual claims whereas the jurisdiction of the Commission extends only to group or tribal claims. ${ }^{17}$

Nevertheless, within the framework of claims for land, the provisions of the Act allow inclusion of evidence which is peculiarly Indian in nature. As has been noted, the matter of treaty and nontreaty cases was finally settled, but further discussion is in order. Ostensibly, where the government outlined Indian holdings in treaties, the land in question would be more easily defined and accepted in any claim based on such treaty. Where no treaty was made, occupancy and use would have to be determined by historical and anthropological evidence. Actually, it is necessary to establish such use and occupancy whether or not boundaries were defined

\footnotetext{
16 Otoe and Missouria Tribe v. United States, 2 Indian Claims Commission, 335, 365 (1953).

17 Fort Sill Apaches v. United States, 1 Indian Claims Commission 137 (1949).
} 
by treaty. According to clause three, it is noted that claims may arise out of negotiations in which fraud, duress, and mutual or unilateral mistake may have played a part. When it is recalled that in many instances treaties were discussed through interpreters involving several Indian languages and perhaps French or Spanish, the possibility of misrepresentation or misunderstanding is apparent. Furtheimore, Indian parties to given treaties were usually nonliterate and dependent on their unlettered interpreters for understanding of the document they signed with an $X$. Both from the point of view of the Department of Justice and from that of the Indians' attorneys, it is desirable to review the circumstances regarding a claim at the time it originated.

It is in this respect that anthropological testimony has come into particular use and is the basis of some disagreement among various scholars. Indian tribes differed in their concepts of territory. Some groups have reliably clearcut ideas about boundaries while others know only their customary habits which the ethnologist must collate and locate in terms of mapping village areas, hunting grounds, and the like. Concern over the problems of use and occupancy have resulted in several major discussions at professional gatherings of anthropologists wherein the points at issue have at least been clarified if not settled to everyone's satisfaction. ${ }^{18}$

$18 \mathrm{Cf}$. "Anthropology and Indian Claims Litigation: Papers Presented at A Symposium Held at Detroit, in December, 1954" [Annual Meeting of the American Anthropological Association], Ethnohistory, Vol. 2, No. 4 (1955), pp. 287-375; Robert A. Manners, "The Land Claims Cases: Anthropologists in Conflict," Ethnohistory, Vol. 3, No. 1 (1956), pp. 7281 ; and Nancy Oestreich Lurie, "A Reply to 'The Land Claims Cases: Anthropologists in Conflict,'" Ethnohistory, Vol. 3, No. 3 (1956), pp. 256-79. Discussion of Indian claims held at the Central States Meeting of the American Anthropological Society held at Bloomington,

\section{Tribal Boundaries}

It is naturally to the interests of the Indians to claim as large an area as possible, whereas the Department of Justice is concerned with reducing or eliminating claims on the basis of evidence presented. Americanists have traditionally mapped tribal boundaries in terms of contiguous territories, and this concept has been generally accepted by Indians' attorneys with modifications of details of given lines suggested by more intensive study of specific tribes. The Department of Justice has questioned this approach insofar as different parts of a tribe's territory may have been used more intensively than others. This has given rise to a theory of land use and occupancy based on "nuclear areas" surrounded by vacuums of relatively little used and scarcely occupied land. A claim might be reduced significantly by this interpretation. As far as anthropologists are concerned, the question remains open whether the traditional techniques of tribal mapping are simply an established convention convenient for academic purposes, or whether such maps reflect the empirical conclusions of many independent researchers in regard to the proper designation of territoriality of human groups generally considered. This reassessment of tribal mapping suggests that neither system can be taken as $T H E$ theory of Indian use and occupancy, but that each case must be discussed in terms of the facts available. ${ }^{19}$

Indiana, in May 1955, as a follow-up of the Detroit Symposium is noted in the last two papers cited above.

$19 \mathrm{Cf}$. Verne F. Ray, [a review of] Harold E. Driver, et al., "Indian Tribes of North America" (Indiana University Publications in Anthropology and Linguistics: Memoir 9, International Journal of Linguistics, Vol. 19, No. 3, Supplement, Baltimore, 1953), in American Anthropologist, Vol. 57, No. 1, Part I, February 1955, pp. 145-46; and Harold E. Driver 
The Department of Justice has tended to emphasize intensive economic utilization of land as the basis of use and occupancy, whereas attorneys for Indians have included in evidence both expert testimony and documentary information regarding seasonal and noneconomic factors. Game and plant life, it is argued, had to be allowed to multiply to assure a regular supply of food. Thus, given areas might be intensively used only for brief seasons. Or, certain areas of limited economic activities might have tremendous social significance for a group so that the loss of a particular tract of land worked a real hardship in the established life of the people. Thus, the gathering of certain plant foods such as berries in the Plateau area might not have meant economic necessity, but did represent an important seasonal activity which helped underscore an identifying characteristic of tribes in the area. It was also pointed out that in the Plateau given lands were prized simply because they were isolated and not intensively used, except in connection with the vision quest. For a group to exist in its customary manner, it was necessary for men to seek visions which required lonely retreats. Many tribes had areas that were considered dangerous or sacred and were thus seldom visited. These areas, however, held an important value in the ethos of such groups and caused a sense of loss in their desecration by white occupancy or by removal of the Indians from a familiar terrain.

Whether an interpretation of "bread alone" is to be made, or whether the broad jurisdictional provisions allowing of extraordinary claims will be interpreted to include loss in a total way of life, as real as the loss of the land, remains the province of the Commissioners. However, a certain selectivity of

[a reply to Verne F. Ray] in American $A n$ thropologist, Vol. 58, No. 1, February 1956, pp. 184-85. data in this regard is inevitable depending on which attorneys propound questions put to expert witnesses.

Various precedents have been adduced to insist that a claim must be based on exclusive use and occupancy by a particular tribe. ${ }^{20}$ Generally, this would seem a reasonable demand. Temporary claims to disputed territories would lead to endless litigation, and, after all, the suits are brought against the United States, not between tribes. However, this circúmstance has made attorneys reluctant to press any claims regarding shared lands. It is common knowledge among anthropologists that certain lands were known as neutral grounds, such as the immediate vicinity of given natural resources, or were areas reserved for intertribal games. Two or more tribes could conceivably hold an equity in such lands and derive a significant part of their sustenance or social identity therefrom. In other instances, the recognized owners of a given area permitted neighbors to visit and share in the local resources as occurred in the Celilo fisheries on the Columbia River. Sometimes, an apparent case of mutual land use cannot be taken at face value. The influence of such leaders as Tecumseh led to statements by Indians in treaty negotiations which are masterpieces of vagueness about tribal boundaries and an embarrassment to the speakers' descendants. The seeming obtuseness concerning boundaries or specific tribal areas was a ploy designed to hamper discussions that might lead to land cessions. ${ }^{21}$

\footnotetext{
${ }^{20}$ See United States ex rel Walapai Tribe v. Santa Fe Pacific Railroad Company, 314 U.S.

${ }^{21}$ This is admittedly an interpretation with which the Commissioners may choose to disagree, but it has the virtue of being an independent conclusion reached by at least one other ethnologist who has reviewed the data on various tribes in the Great Lakes regionpersonal communication of Anthony $\mathrm{C}$. Wal-
} 339. 
The astonishing complications possible in regard to the location of given tribes are well illustrated in the case of the Ioway, Sac and Fox, and Omaha, Docket 138. On August 19, 1825, these tribes along with some Sioux and Otoes signed a treaty at Prairie du Chien whereby a designated area in northern Missouri and western Iowa, known as the "Trust Lands," was secured by the Ioway, Sac and Fox, and Omaha. It was understood that at some future date the government would enter into another treaty establishing lines between the tribes. Such a treaty was never ef-. fected, and the petitioner Indians claim that they were misinformed concerning the next treaty signed at Prairie du Chien on July 15,1830 . This was construed by the government as a treaty of cession, whereas the Indians believed that if they relinquished their common right to the land, the government would then designate the specific tribal areas within the "Trust Lands." Meanwhile, in the intervening five years, the three tribes began to work out their own areas of use and occupancy.

Documentary evidence was presented showing that the Indians divided lands in practice and did not wander over them haphazardly. The Indians' witness blocked out the tribal lands as had been done frequently in nontreaty cases. Thus, it was with some surprise that the expert found the propriety of his action challenged by the defense. The curious upshot was that other experts were then called in to testify to the good faith, scholarly conventionality, and academic correctness of the first expert's opinion.

\section{Indian Claims}

The question of tribal replacements in given territories during historic times is exceedingly complex in such areas as the Ohio Valley-Great Lakes region. A lace, University of Pennsylvania, Philadelphia, Pa. shift in locations was set in motion by the Iroquois wars of the seventeenth century, and further disturbance was produced when England and the United States contested for ownership of the country. This situation prompted the Department of Justice to finance a center for ethnohistorical study at Indiana University to do research in approximately 100 claims in the Great Lakes region. $^{22}$ Just how long a tribe had to be using and occupying an area exclusively before it was lost to the United States has never been determined precisely in making claims for restitution. Generally, however, the Commissioners have been interested in materials relating specifically to the time of origin of a claim rather than to the prehistoric past.

After a tribe has actually proven a case of use and occupancy, a second phase of historical analysis comes into play: The actual value of the land must be determined, and gratuities granted a tribe in the past must be assessed for possible offsets against the eventual judgment. A certain reluctance on the part of Indians' attorneys to discuss Indian claims in the public prints reflects anxiety over the possible size of the still undetermined figure of the total amount of Indian claims. It is believed that what public sympathy might be aroused in the interests of the Indians would be more than offset by the average taxpayer's fears about the drain on the public purse. These fears seem somewhat groundless on the basis of figures available through January 5, 1956. Of the 102 claims decided by the Commission by that date, the Indians have been allowed recovery in 21 cases. The amount of money has been reduced from at least $\$ 890,000,000$ claimed to

22 See Bulletin of the American Anthropological Association, Vol. 2, No. 1 (1954), p. 17 for announcement and description of the Center. 
$\$ 13,283,477.25$ awarded. $^{20}$ This is a percentage of awards to claims of 1.5 per cent.

It should be noted that the early cases tended to be reduced to a striking degree since the size of claims was necessarily estimated somewhat provisionally. It was uncertain at the outset what sort of legal theory ought to underlie the attorneys' preparations, and thus, in some instances, a practice common in other types of claims was utilized. That is, an excessive amount was set forth with the tacit understanding that the attorneys for the petitioners and for the defense would engage in a sort of legal haggling and reduce it to about what the Indians' attorneys had hoped to obtain in the first place. As more anthropologists took part in these cases and became more sophisticated in the operations of the law, they realized that they could exercise some control over phases of the cases that antedated the period in which their services were requested. Consequently, where a witness feels that a petition does not conform to the facts as he knows them, the petition can be amended to form an accurate statement of the claim on the basis of available data. In other instances, claims may be enlarged as anthropological evidence indicates the propriety of such a course.

\section{Number of Caşes}

It may be noted that many of the illustrations used in this article are merely reflections of the problems raised and the types of evidence used in Indian claims without reference to the final determination of the cases. This

23 These figures are based on a compilation made by the Commission. Of the total of 102 claims decided, only 78 claimed specific amounts giving the total of $\$ 890,000,000$. No definite amount was claimed in the rest of the cases, but the Commission has advised that the amount claimed, as estimated, was between $\$ 1,000,000,000$ and $\$ 1,200,000,000$. circumstance is related to the huge number of claims filed, approximately 852 , and the necessarily slow process of dealing with them. Since so many cases are still pending, it is rather early to attempt any sort of general assessment of the Indian Claims Commission Act. Nevertheless, certain trends may be noted. First, these claims will simply not be settled when the Commission expires in 1962, even though all of the cases may be heard and adjudicated by the Commission. Cases can be, and generally are, appealed to the United States Court of Claims by either party. They can then be taken to the Supreme Court, or at least a petition may be filed for that Court to hear them. Thus far, the Supreme Court has declined to hear any such appeals. However, the frequent application to the Court of Claims alone offers a certain reasonable basis for the somewhat jocular estimates expressed by anthropologists that they look forward to twenty-five years of employment in Indian claims.

While the amount awarded may not come close to the amount claimed in Indian cases, there remains the possibility that some tribes will be put in possession of large amounts of money. No definite arrangements have been made for this eventuality, although carefully planned economic and social programs have been developed by tribes which have been awarded judgments in the past, such as the Menominee and the Ute. Concern has been expressed by both Indians and interested white people that the result may be similar to the unfortunate experiences of the famous "oil Indians." Even where awards are small, they might have enduring value if invested for tribal benefits rather than simply divided among the individual members of the group. However, the Indians are understandably concerned with personal payments, associating the management of their re- 
sources with part of their general grievances against the government.

The chances are that even the tribes that actually win awards will not be completely satisfied. As far as some tribes are concerned, the idea that the Commission would settle Indian grievances once and for all has already fallen short of its goal. Although an occasional Indian will recognize an unfortunate and sometimes unwarranted tendency to self-pity on the part of his fellows, lost claims or unregulated recoveries may contribute further complications and grievances despite the benevolent intent of the Indian Claims Commission Act. It is useless, however, to argue that the Act should have never been put into effect. Obviously, the same process would take place, and with less satisfactory techniques and results, by the earlier means of Acts of Congress and recourse to the Court of Claims. Although the Indian Claims Commission Act contains revolutionary provisions in the light of American legal history, it remains a legal instrument and must be assessed as such. It cannot be expected to work as a cure-all for Indian complaints of a socio-historical nature involving intangible factors beyond any possible legal interpretation.

Through the provisions of the Act itself, Indians were informed by their superintendents of the existence of the Commission and of their right to bring claims. This educational function might be extended to prepare programs for those Indians likely to receive awards. Where recoveries may be small or nothing will likely be gained from a claim, Indians should be informed of what the Act can do and cannot do, and why this is the case. Anyone familiar with Indians knows that these are not easy tasks to carry out since it was the generalized sense of Indian discontent itself that led to efforts to satisfy claims as a means of furthering effective administration of Indian affairs. Nevertheless, the cases are being settled slowly, and with the increasing economic sophistication of at least the younger Indians, there is yet time to develop policies to further implement the fundamental philosophy of the Indian Claims Commission Act. 